\title{
A divatipar egészségvédelmi szabályozása
}

\author{
Bogár Nikolett dr. ${ }^{1}$. Túry Ferenc dr. ${ }^{2}$ - Pászthy Bea dr. ${ }^{3}$
}

\author{
${ }^{1}$ Bioextra Zrt., Budapest \\ ${ }^{2}$ Semmelweis Egyetem, Általános Orvostudományi Kar, Magatartástudományi Intézet, Budapest \\ ${ }^{3}$ Semmelweis Egyetem, Általános Orvostudományi Kar, I. Gyermekgyógyászati Klinika, Budapest
}

\begin{abstract}
A divatiparra vonatkozó egészségvédelmi szabályozások hiányosak. A karcsúság elérését célzó szociokulturális nyomás a divatiparon belül fokozott, a divatmodelleket gyakran késztetik kórosan alacsony testsúly elérésére, ami pszichológiai abúzusnak felel meg. Ezért a modellek közt az evészavarok prevalenciája magasabb az átlagpopulációhoz képest. A divatvilág veszélyei között ezeken túl a szexuális abúzus, a financiális visszaélések, illetve a fiatalkorúak foglalkoztatásával kapcsolatos szabályozatlanság említendő. A kockázatok csökkentése érdekében fontos volna nemzetközi szabályozásokat bevezetni a divatszakmában. Az erre irányuló kezdeményezések először 2006-ban jelentek meg Spanyolországban: a modellek foglalkoztatásának feltétele volt az egészséges tápláltsági állapot alsó határától minimálisan elmaradó testtömegindex $(18,0)$ elérése. Később Franciaországban az evészavarok gyakoriságának mérséklésére törvénybe foglalták a modellek kötelező egészségügyi vizsgálatát, illetve az utólagosan módosított divatfotók megjelölését. E szabályozások azonban könnyen kijátszhatók. A törvényhozás mellett különböző szervezetek alkottak olyan irányelveket, amelyek a modellek egészségvédelmét szolgálták. Ezek az iránymutatások elsősorban a biztonságos munkavégzésre, a fiatalkorúak foglalkoztatásának korlátozására és az emberi méltóság megtartására irányulnak. A divatszakmában előforduló feszültségek vezettek továbbá olyan nonprofit szervezetek megalakulásához, amelyek a modellek érdekvédelméért dolgoznak. A divatmodellek egészségvédelmét célzó jogi szabályozás a mai kultúrában domináns karcsúságideál megváltoztatását is szolgálná, mert a szociális tanulás révén a divatot követő átlagnépesség utánozza a modelleket. A divatmodellek egészségének védelme tehát népegészségügyi vonatkozással is bír.
\end{abstract}

Orv Hetil. 2021; 162(23): 905-910.

Kulcsszavak: divatipar, divatmodellek, egészségvédelem, evészavarok, anorexia nervosa

\section{Health protective regulation of the fashion industry}

The fashion industry is lacking sufficient health protective regulations. There is an increased sociocultural pressure to be thin. Fashion models are often forced to reach abnormally low body weight, which can be regarded as psychological abuse. This leads to a higher prevalence of eating disorders among models compared with the general population. Some of the other dangers associated with the fashion industry are sexual harassment, financial exploitation, and unregulated minor labour force. To reduce these risks, it is crucial to introduce international regulations in the fashion industry. The first initiative for such regulations took place in Spain in 2006 when the condition for models' employment was for their body mass index (BMI) not to drop below 18.0, which is close to the low end of healthy BMI. Later in France, to decrease the prevalence of eating disorders, a legislation on compulsory medical examination for models was made. Also, retouching of photos had to be disclosed. Regulations like these, however, can easily be eluded. Different organisations implemented guidelines, such as establishing safe working conditions, limiting underage labour force, and maintaining dignity to protect models' health. Tension within the fashion industry led to the formation of non-profit organisations seeking the protection of models' interest. Regulations protecting models' health in the fashion industry would encourage society to adjust its predominant ideal for thinness. Just as the general population tends to follow fashion trends portrayed by fashion models, so would they likely imitate the new look of models. Hence, the protection of models' health goes beyond the fashion industry. It has public health implications as well.

Keywords: fashion industry, fashion models, health protection, eating disorders, anorexia nervosa

Bogár N, Túry F, Pászthy B. [Health protective regulation of the fashion industry]. Orv Hetil. 2021; 162(23): 905-910.

(Beérkezett: 2020. december 9.; elfogadva: 2020. december 31.) 


\section{Rövidítések}

$\mathrm{BMI}=($ body mass index $)$ testtömegindex $;$ COVID $-19=\left(\mathrm{co}^{-}\right.$ ronavirus disease 2019) koronavírus-betegség 2019; DSM-5 = (Diagnostic and Statistical Manual of Mental Disorders, Fifth Edition) diagnosztikai klasszifikációs rendszer a pszichiátriai zavarok kezelhető formában történő bemutatására; USA = (United States of America) Amerikai Egyesült Államok

A divatmodellek élete sokak számára vonzónak tünhet. A csillogó hivatás azonban kevéssé szabályozott, számos lehetőséget kínálva a modellek kihasználására, pszichológiai, szexuális és pénzügyi értelemben is.

A közösségi médiában egyre több divatiparbeli résztvevő szólal fel a divatszakmában előforduló nehézségekről. A karcsúság iránti állandó nyomás, a kiszámíthatatlan munkakörülmények, a bizonytalan megélhetés, az ügynökségek és divatházak által alkalmazott, sokszor abuzív kommunikáció is hozzájárul a modellek testi és mentális egészségének károsodásához $[1,2]$.

A divattervezók szerint a sovány küllem elengedhetetlen kelléke a divatiparnak, mely a modellekre úgy tekint, mint élő ruhafogasokra, vagyis minél kevesebb test van a ruhában, annál kívánatosabban lehet a ruhát önmagáért prezentálni $[3,4]$. A krónikus diétázás következtében kialakuló tápanyaghiány hosszú távon számos testi szövődményhez vezethet (például osteoporosishoz, amenorrhoeához, cardialis szövődményekhez) [5]. A különböző testsúlykontrolláló módszerek (önhánytatás, laxatívum, diuretikum, drogabúzus) a só-víz háztartás egyensúlyának felborulását okozhatja. Nem szabad megfeledkezni arról, hogy a modellkedést választó lányok gyakran még kiskorúak, fejlődésben vannak, így egészségvédelmük különösen fontos.

Az evészavarok prevalenciája magasabb az átlagpopulációhoz képest a divatszakmában [6]. Ehhez az egyéni tényezőkön kívül jelentős mértékben hozzájárul a karcsúságideál szociokulturális nyomása, amelyet a divatipar szereplői, a divatházak és ügynökségek képviselnek, sokszor közvetlenül vagy közvetetten fogyásra ösztönözve az egyébként is vékony testalkatú modelleket [7]. A modellekkel felvett interjúk alapján derült fény arra, hogy gyakran pszichológiai abúzusról van szó. A profitszerzés érdekében az ügynökök a modellek testi egészségét kockáztatják, amihez a modellek (illetve kiskorúak esetében hallgatólagosan a szüleik is) hozzájárulnak - ez egyfajta tudattalan összejátszást, kollúziót jelent [2].

Korábbi kutatásunk során 53 női modell testtömegindexének (BMI) átlaga 16,1 volt [2]. Ez az érték a DSM5 pszichiátriai betegségosztályozási rendszer diagnosztikus kritériumai szerint a mérsékelten súlyos anorexia nervosa testsúlytartományának felel meg [8]. A megkérdezettek 92\%-ának BMI-je 18 alatt volt, holott a nókre vonatkozó egészséges alsó határérték 18,5. A kutatásban részt vevők között a legalacsonyabb BMI-érték 14,2 volt, ami a DSM-5 szerint extrém súlyos anorexiát jelent.
A jelen összefoglalás áttekinti a közelmúlt nemzetközi divatpiacain bevezetett szabályozásokat. E szabályoknak kettős céljuk van: egyrészt a modellek egészségvédelme, másrészt a divatot követő átlagnépességre gyakorolt hatás következtében a karcsúságideál nyomásának csökkentése. A modelltanulás következtében az arra fogékony közönség (elsősorban fiatal nők) internalizálhatja az extrém karcsúságideált, ami hozzájárulhat a klinikai vagy szubklinikai súlyosságú evészavarok kialakulásához [9]. Írásunk célja továbbá az, hogy az egészségügyben dolgozó szakemberek és az egészségpolitika figyelmét ráirányítsuk egy népegészségügyi vonzatú kérdésre a nemzetközi példák alapján.

\section{A divatmodellek szereplésére vonatkozó egészségügyi szabályozások különböző országokban}

A túlzottan vékony modellek foglalkoztatása ellen az elmúlt években több országban rendeleteket hoztak. A modellhivatás gyakorlását minimális BMI-értékhez kötötték először 2006-ban Spanyolországban, majd Olaszországban. Később Franciaországban és Izraelben is hasonló szabályozás lépett életbe.

Ez összefüggésben állhat olyan tragikus eseményekkel, melyek a modellvilágban a karcsúság túlhajszolása következtében történtek meg. Egy uruguayi női modell testvérpár, Luisel Ramos és Eliana Ramos egymást követő években vesztették életüket (Luisel 2006-ban, 22 évesen hunyt el, míg Eliana 2007-ben, 18 évesen). Mindketten anorexia nervosában szenvedtek, halálukat szívelégtelenség okozta [10]. Egy francia modell, Isabelle Caro 2010-ben halt meg 28 évesen [11].

A Spanyolországban 2006-ban életbe lépett szabályozás értelmében csak minimum 18-as BMI-vel volt szabad modelleket foglalkoztatni a madridi divathetek kifutóin, amit orvosi vizsgálat biztosított a testmagasság és a testsúly mérésével [12]. Ezt a szabályt azonban sokan kijátszották - ezt személyes interjúk tanúsítják, illetve az első szerző (B. N.) modellként résztvevője volt a madridi divatheteknek [2]. A divatbemutatókat megelőző mérésekre a modellek ügynökei fel voltak készülve, előre kiszámították modelljeik BMI-jét, s a hiányzó testsúlykilogrammokat derékra rögzíthető súlyokkal, valamint fehérnemúkbe applikált nehezékekkel vagy vízitatással pótolták. A manipulációk megakadályozása érdekében a hatóságok nem tettek lépéseket. Ez a szabályozás tehát nem érte el célját, s a kifutón továbbra is túlzottan vékony modellek jelentek meg.

2012-ben Izrael is korlátozásokat vezetett be. Orvosi egészségügyi alkalmassági vizsgálatot tettek szükségessé, mely kijelenti a BMI minimum 18,5-es értékét [13]. Az igazolás 3 hónapig érvényes. Továbbá a nyomtatott sajtó köteles jelezni, ha a felhasznált fényképeken szereplő modellek alakja utómunkával lett vékonyabbra szerkesztve. Ez volt az első, törvényileg előírt intézkedés az 
evészavarok előfordulásának visszaszorítására, védve ezzel nemcsak a modelleket, hanem az átlagnépességet is.

A divatipari nagyhatalmak közül Franciaország különösen érintett a soványság kultuszában: a „párizsi soványság” („Paris thin”) fogalommá vált a modellek és ügynökök körében, s azt a túlzott soványságot jelenti, amelyet az „haute couture” divatházak bemutatói megkövetelnek. Egy divatújság szerkesztője szerint a modellek ideális testméretei ott kezdődnek, ahol a kórházi felvétel határa van [4].

2016-ban Franciaországban törvényileg szabályozták a túl vékony modellek fellépését a kifutókon [14]. A munkavállalást orvosi vizsgálatnak kell megelőznie, mely igazolja, hogy a modell testsúlya a megfelelő tartományban van, illetve a modell jó általános egészségnek örvend. A vizsgálat a BMI megállapításán túl vérnyomásés pulzusmérést, a szívhangok vizsgálatát foglalja magában. Személyes beszámolók alapján valóban eltanácsolják a betegesen vékony modelleket az ügynökségektől, s egészségük helyreállását követően kapnak újra lehetőséget a modellmunkára Párizsban. Ugyanebben az évben egy további szabályozás is életbe lépett, melynek értelmében az utólagosan módosított képek esetén a technikai beavatkozást fel kell tüntetni, s egyértelmúvé kell tenni a magazinokat olvasók számára, hogy szerkesztett képeket látnak. A rendelkezések célja a fiatalkori anorexia nervosa kialakulásának prevenciója, valamint a modellek egészségének védelme volt.

A szabályozások be nem tartása 75000 eurós bírságot vagy 6 hónap szabadságvesztést vonhat maga után. A párizsi divathetek modelljei azonban továbbra is extrém vékony ideált közvetítenek, s az a benyomás keletkezik, hogy az intézkedések nem vezettek eredményre. További probléma, hogy a túlzott vékonyságuk miatt Párizsból eltanácsolt modellek más országokban vállalhatnak munkát, valamint az is, hogy a dokumentum kiállítása hat hónapra szól, s ez az idő bőségesen elegendő jelentős súlyvesztésre, s ezáltal a modell újra megfelelhet a divatszakma extrém méretkövetelményeinek. Az igazolás kiállítása egyszerü formaság is lehet, valós fizikai vizsgálat nélkül.

A konkrét szabályozásokon túl számos ország, mint például Dánia, az Egyesült Királyság vagy az USA alkotott meg különböző irányelveket az elmúlt években, melyek betartását szorgalmazták a divatszakma dolgozói számára [15]. Ezek az irányelvek fóképp a megfelelő bánásmódra, az egymás iránti tiszteletre és a visszaélések korlátozására irányulnak.

Jelenleg a magyar divatpiacon nincs érvényben semmilyen korlátozás a modellek egészségvédelme érdekében.

\section{Nonprofit szervezetek aktivitása a modellek egészségének védelméért}

A hivatalos intézkedések mellett számos nonprofit szervezet is igyekszik felhívni a figyelmet a divatszakmában szükséges szabályozásokra. Modellügynökségek, divat- házak bevonásával igyekeznek a szakmát a modellekkel szembeni etikusabb bánásmódra bírni. Ezek a szervezetek nagyon fontosak lehetnek a kezdő, sokszor kiskorú modelleknek és szüleiknek is, hiszen kívülállóként nehéz tájékozódni a divatvilágban. Ezen platformok által ismerhetjük meg a szakmában fellelhető, sokszor rejtett és szabályozatlan szervezeti múködésmódokat, illetve kaphatunk betekintést a gyakran abuzív magatartásokra. A modellek nemcsak a karcsúság iránti túlzott nyomásnak vannak kitéve, hanem gyakran szexuális abúzus áldozatai is, valamint a bérek nem kiszámítható rendezése és az átláthatatlan extra költségek miatt financiális kihasználásnak is ki vannak téve. A Humans of Fashion, a Model Law és a Models Empowered olyan, a modellek érdekeiért fellépő szervezetek, amelyeket egykori modellek alapítottak, és jogászok, ügyvédek, pénzügyi tanácsadók, dietetikusok, pszichológusok, coachok és egyéb szakemberek bevonásával támogatják a modelleket.

A divatvilágban növekvő igény mutatkozik a biztonságos munkakörülmények megteremtésére. 2020-ban jelentette be az Elite Model Management USA, egy nemzetközileg elismert modellügynökség, hogy egészségügyi biztosítást nyújtanak modelljeiknek [16]. Ez az első olyan ügynökség, amely ilyen lehetőséget nyújt. A biztosítás kiterjed a sürgósségi betegellátásra, valamint az utazási kellemetlenségek kompenzálására is.

Az irányelvek közül a legszélesebb körben megvalósulni látszik az LVMH-Kering Model Charter, melynek kidolgozásában James Scully, egykori „casting director” is részt vett. Ö világhírû modellekkel dolgozott együtt karrierje során, aktív szószólója a modelleket érintő diszkrimináció, a negatív bánásmód, a szakmai hierarchia elleni fellépésnek.

2017-ben az LVMH és a Kering francia luxusvállalatok (amelyek többek közt a Louis Vuitton, Fendi, Céline, Christian Dior, Givenchy, Marc Jacobs, Gucci, Saint Laurent, Bottega Veneta, Alexander McQueen és Balenciaga márkák tulajdonosai) megalkották „A divatmodellekkel való munkakapcsolatról és azok jóllétéről szóló chartá"-t. A kezdeményezés kiemelten fontos a modellek biztonságos munkavégzésének szempontjából. A fóbb pontok kitérnek a ruhaméret korlátozására, a fiatalkorú modellek munkavégzésére, a munka során biztosítandó élelmezésre és a privát öltözőhelyiségek kialakítására [17]. Vállalásuk szerint nem dolgoznak 32-es női és 42-es férfiméretet hordó modellekkel (francia méretezési standard). A modelleknek hat hónapnál nem régebbi orvosi egészségügyi vizsgálattal kell rendelkezniük, amely igazolja megfelelő egészségi állapotukat a biztonságos munkavégzéshez. A márkáknak továbbá elérhetőséget kell biztosítaniuk pszichológusokhoz/terapeutákhoz a munkavégzés ideje alatt. A charta kimondja, hogy a munkák során a kliensek kötelesek tápláló ételeket és italokat biztosítani az ott dolgozó modellek számára, az alkoholos italok felszolgálása pedig engedélyköteles és korhatárhoz kötött. A modellekhez a munka során tisztelettel és profizmussal kell fordulni, nem tehetők ki köz- 
vetlen veszélyt jelentő vagy megalázó helyzeteknek. A két óriásvállalathoz tartozó márkák vállalják, hogy nem alkalmaznak 16 évnél fiatalabb modelleket felnőttkollekciók bemutatására, valamint a 16-18 év közötti modellek nem dolgozhatnak este 10 és reggel 6 óra között.

Az egyezmény kitér a vállalható munkaórák összehangolására is a helyi törvényekkel. A chartában foglaltak betartását ellenőrző bizottság fogja felülvizsgálni [17].

A modellek személyes elmondásai (folyamatban lévő, még nem közölt felmérésünk interjúszövegei) szerint sok pont valós változást hozott, a leginkább az, amelyik az étkezési ellátás biztosításáról és a fiatalkorú modellek munkavégzési korlátozásairól szól. Ám az egészségügyi alkalmassági vizsgálatokat gyakran meghamisítják, sokszor valós testi vizsgálat nélkül állítják ki az igazolást. Problémát okoz az is, hogy a hat hónapra szóló engedély túl tág időintervallum, ugyanis szigorú diétával l-2 hónap alatt jelentős súlyvesztést lehet elérni, ezzel továbbra is kielégítve a divatszakma beteges ideálját.

Egy 2012-ben alapított, New York-i székhelyú érdekképviseleti szervezet, a Model Alliance a modelleket és a divatszakma egyéb képviselőit érintő irányelvek alkotásában és az azokat érintő oktatásban érdekelt [18]. Alapítója Sara Ziff, aki korábban szintén modellként dolgozott. Missziójuk az igazságos bánásmód, az egyenlő lehetőségek és a fenntartható gyakorlatok kivívása a divatszakmán belül. Segítik a szakmabelieket a rájuk vonatkozó jogszabályok megismertetésével.

A Model Alliance közremúködésével készült tanulmányban hét, divatszakmán belüli intézkedéstervezet kivitelezhetőségét vizsgálták modellek körében [19]. A javasolt irányelvek között szerepelt a nagyobb méretû bemutató ruhadarabokra való igény, a minimum-BMI meghatározása modellmunkák végzéséhez és a 30 perces szünetek, az étkezés biztosításával a hat óránál tovább tartó munkák esetén. A modellek által a leginkább favorizált intézkedések a biztonságos munkavégzésre és a rendezett anyagi kompenzációra vonatkoztak. A modellek a legkevésbé a minimum-BMI meghatározását tartották eredményesnek. A különböző típusú modellmunkákat végző csoportok eltérôen értékelték az egyes intézkedések szükségességét. Míg a beanty modellek (azaz fóleg az arcukkal dolgozó, fotókon szereplő modellek) pozitívan értékelték a nagyobb ruhaméretek bevezetését, ez az elsősorban kifutókon dolgozó modellekre nem volt igaz.

Fő küldetésüknek tartják felhívni a divatszakma figyelmét az evészavarokra, a bántalmazás és a diszkrimináció bármely formájára, a financiális átláthatóság hiányára, a megfelelő panasztételi gyakorlat hiányára, a követendô szakmai irányelvek hiányára és az azokkal a modellekkel szembeni bánásmódra, akik nyíltan beszélnek a szakmai problémákról. 2020-ban a COVID-19-pandémia miatt sújtott modellek anyagi támogatásával kapcsolatban is támogatták közösségük tagjait.

Ök hozták létre a Respect programot, melynek célja, hogy a múvészi kreativitás megélése ne jelentsen vissza- élést, bántalmazást, diszkriminációt vagy megalázást a kreatív munka egyik szereplőjének sem. A program modellek által alkotott átfogó szakmai sztenderdeket tartalmaz. Fontos részét képezi az edukáció is, melynek során a divatszakma képviselői megismerhetik jogaikat és lehetôségeiket [20].

A Condé Nast globális médiavállalat kiadott egy magatartási kódexet, melyet minden partnerüknek szükséges alkalmaznia [21]. Kijelentik, hogy csak olyan modellekkel dolgoznak, akik betöltötték a 18. életévüket. A fehérnemút, fürdőruhát, áttetsző öltözéket, meztelenséget vagy szexuálisan szuggesztív pózokat igénylő körülményeket előre jelzik a modelleknek, akik beleegyezésüket adhatják, vagy megtagadhatják a munkavégzést. Vállalták, hogy minden munka során privát öltözőhhelyet biztosítanak a modellek számára, és nem hagyják óket egyedül a stáb egyetlen tagjával sem.

Egy holland nonprofit szervezet, The Model's Health Pledge, szintén a modellek egészségéért és megfelelő munkakörülményeiért hozott létre egy 13 pontból álló szabályzatot, melyet több befolyásos divatszakmabeli partner is alkalmaz, aláírásukkal vállalják annak betartását. Platformjuk lehetőséget nyújt arra is, hogy a nem megfelelő munkahelyi bánásmódot jelentsék, s annak szakszerü kivizsgálását vállalják. Mottójuk: „Without ethics, no aesthetics" (nincs esztétika etika nélkül ) [22].

\section{Következtetések, javaslatok}

Az elmúlt években a modellek egyre inkább igyekeznek erősíteni érdekvédelmüket a közösségi média felületeinek köszönhetően. Hatékony intézkedések azonban alig történtek egészségvédelmük érdekében. Különböző nemzetek bevezettek ugyan bizonyos szabályokat, ám ezek gyakran könnyen kijátszhatók.

A divatipar sok lehetőséget teremt a modellek testi és mentális, valamint egzisztenciális kihasználására [2]. A jelenleg fennálló szabályozások nem kellőképpen kidolgozottak, továbbá a legtöbb országban nem áll érdekvédelmi szervezet a modellek mögött.

Az egyre szaporodó nonprofit szervezetek igyekeznek pótolni ezeket a hiányokat. Ezek a modellek testi és mentális egészségvédelmén túl a jogi szabályozást, a szexuális visszaélések visszaszorítását, az anyagi kompenzáció időbeli kifizetését, valamint az egyenlő bánásmód biztosítását szorgalmazzák.

Az elmúlt években több, sokat ígérő intézkedést vezettek be Európa-szerte az extrém vékony szépségideál visszaszorításáért. Spanyolországban 18-as BMI-minimumértéket állapítottak meg a divatheteken való részvételhez, míg Franciaországban egészségügyi alkalmassági igazolás szükséges a modellmunkák végzéséhez. Ezek a kezdeményezések szükségszerúek, ám sajnos könnyen kijátszhatók, a divatszakma sokszor nem tartja be az intézkedéseket, amelyek megszegése nem jár komoly szankciókkal. A modellek egészségvédelme érdekében 
azonban fontos lenne ezeknek a kezdeményezéseknek a betartása, illetve újabbak kidolgozása.

A modellek egészségének védelme érdekében a következő ajánlások fogalmazhatók meg.

1) A modellhivatás betöltéséhez független orvosszakértői vizsgálatra van szükség, amely kiterjed a tápláltsági állapot ellenőrzésére, azaz a megfelelő BMI-re, illetve a pszichológiai háttértényezőkre (elsősorban az evészavar-kockázat jeleire). Tápláltsági minimumnak a normális testsúlytartomány alsó határa javasolható: nóknél 18,5-es, férfiaknál 20-as BMI. Dilemma, illetve ellenérv lehet, hogy e korlátozások során nem szabad figyelmen kívül hagyni az alkatilag karcsú modelleket. Érdemes-e eltiltani őket a modellhivatástól az elérhetetlen karcsúságideál promotálására hivatkozva, vagy bizonyos esetekben őket is lehetne alkalmazni? Vajon ez nem jelenti-e egyes testalkatok diszkriminálását csakúgy, mint ahogyan azt jelenleg is látjuk ebben a világban?

2) Az egészségügyi ellenőrzéseket rendszeres időközönként lenne érdemes ismételni annak elkerülésére, hogy az első vizsgálatot követően néhány hónap alatt jelentős súlyvesztésen essenek át a modellek. Ezzel kapcsolatban érdemes megemlíteni egy figyelemre méltó analógiát. Sportolók esetében az egészségvédelem érdekében rendszeres doppingellenőrzések vannak, igen szigorú eltiltási szabályokkal. Váratlanul, szúrópróbaszerűen mintavételre kötelezhetik őket az ellenőrök. Ha a sportolók egészségvédelme ennyire fontos, akkor a modelleké miért nem?

3 ) Lényeges kérdés a modellek munkavállaláshoz szükséges minimuméletkorának megállapítása is. Egyes gyakorlatok szerint 16 éves kor alatt nem foglalkoztathatók modellek New York és az európai divatfóvárosok kifutóin, Ázsiában azonban ez a korlátozás nincs életben. Megfontolandó lenne a korhatár megemelése 18 éves korra. Ez indokolt lenne mind a testi fejlődési folyamatok befejeződése (a csípőméret változása), mind a pszichés érés szempontjából.

4) Szükség volna a modellügynökségeken dolgozó szakmai team bóvítésére. A túlzott soványság egészségügyi kockázataiban jártas személyi edzőknek, dietetikusoknak, pszichológusoknak kellene segíteniük a modelleket a divatipar méretkövetelményeinek elérésében, szigorúan egészséges keretek közt.

5 ) Mindezeken felül szükség van a modellek összefogására, saját érdekvédelmi szervezetük kialakítására, melynek segítségével a divatiparban megjelenő problémákkal szemben a megfelelő fórumokon adekvát eszközökkel tudnak fellépni, ezáltal biztonságosabbá téve munkájuk feltételeit.

6) Igen fontos volna a karcsúságideál kulturális nyomásának csökkentése a (vizuális) médiában. Idetartozik az ideális emberi test, illetve tápláltsági állapot szélesebb spektrumú ábrázolása és elfogadása.

A munkaegészségügyi szempontból veszélyes munkakörökben szigorú munkavédelmi szabályok vannak élet- ben. Nem ez történik a kifutókon dolgozó modellekkel, annak ellenére, hogy ók egész karrierjük alatt folyamatosan koplalnak, vagy káros testsúlycsökkentő praktikákat folytatnak [4].

A fenti szabályozások ellenállást váltottak ki a divatiparon belül. Azzal érvelnek, hogy a BMI csupán a tápláltsági állapotra vonatkozik, ugyanakkor nem jelzi a valódi egészségi állapotot, illetve nem veszi figyelembe a különböző népcsoportok testsúlyának genetikai meghatározottságát (például az ázsiaiak ugyanazzal a BMI-vel más tápláltsági állapotban vannak, mint az afroamerikai lakosság). A szabályozást nehéz betartatni, mert a modellek egyéni vállalkozók, nem a divatházak alkalmazottai, így nem érvényesek rájuk a cégek számára kötelező munkavédelmi elő́rások. Ezért inkább az ügynökségeket kellene szabályozni [4].

Végső konklúzióként: a modellek egészségvédelme mellett a karcsúságideál terjesztésének fékezése is fontos szempont, s ennek népegészségügyi vonzata van. Ezért nemzetközi szabályozás megalkotása szükséges az egészségvédelem ezen területén is.

Anyagi támogatás: A közlemény megírása anyagi támogatásban nem részesült.

Szerzői munkamegosztás: B. N. és T. F.: A kézirat terve, irodalmi adatgyújtés, a kézirat szövegezése. P. B.: Irodalmi adatgyüjtés, a szöveg véglegesítése. A cikk végleges változatát valamennyi szerző elolvasta és jóváhagyta.

Érdekeltségek: A szerzőknek nincsenek érdekeltségeik.

\section{Irodalom}

[1] Treasure JL, Wack ER, Roberts ME. Models as a high-risk group: the health implications of a size zero culture. Br J Psychiatry 2008; 192: 243-244.

[2] Bogár N, Túry F. The fashion industry and eating disorders: the dangers of the catwalk. Cambridge Scholars Publishing, Cambridge, 2019.

[3] Clements K. Former Vogue editor: the truth about size zero. The Guardian, July 5, 2013. Available from: http://www.theguardian.com/fashion/2013/jul/05/vogue-truth-size-zerokirstie-clements [accessed: December 6, 2020].

[4] Record KL, Austin SB. "Paris thin": a call to regulate life-threatening starvation of runway models in the US fashion industry. Am J Public Health 2016; 106: 205-206.

[5] Pászthy B. Medical complications in children and adolescents with anorexia nervosa. [A gyermek- és serdülőkorban kezdődő anorexia nervosa szomatikus szövődményei.] Orv Hetil. 2007; 148: 405-412. [Hungarian]

[6] Santonastaso P, Mondini S, Favaro A. Are fashion models a group at risk for eating disorders and substance abuse? Psychother Psychosom. 2002; 71: 168-172.

[7] Dauxerre V. Size zero: My life as a disappearing model. HarperCollins Publishers, New York, NY, 2017.

[8] American Psychiatric Association (APA). DSM-5. APA, Arlington, VA, 2013.

[9] Groesz LM, Levine MP, Murnen SK. The effect of experimental presentation of thin media images on body satisfaction: a metaanalytic review. Int J Eat Disord. 2002; 31: 1-16. 
[10] Wikipedia. The free encyclopedia. Available from: https://en. wikipedia.org/wiki/Eliana_Ramos [accessed: November 18, 2020].

[11] Wikipedia. The free encyclopedia. Available from: https://en. wikipedia.org/wiki/Isabelle_Caro [accessed: November 18, 2020].

[12] Madrid bans waifs from catwalks. BBC News, 13 September 2006. Available from: http://news.bbc.co.uk/2/hi/5341202. stm [accessed: November 19, 2020].

[13] Ostroff N. Israel first country to introduce law on skinny models. BBC News, 20 March 2012. Available from: https://www.bbc. com/news/newsbeat-17447826 [accessed: November 19, 2020].

[14] Loi no 2016-41 du 26 janvier 2016 de modernisation de notre système de santé (1). Journal Officiel de la République Française, 27 janvier 2016.

[15] Sykes S. Six countries taking steps to tackle super-skinny models. Euronews, 6 September 2017. Available from: https://www. euronews.com $/ 2017 / 09 / 06 /$ counties-fighting-underweightmodelling [accessed: November 19, 2020].

[16] Lockwood L. Elite Model Management to offer insurance for models. Women's Wear Daily, November 12, 2020. Available from: https://wwd.com/business-news/media/elite-modelmanagement-to-offer-insurance-for-models- 1234655121 [accessed: November 19, 2020].
[17] Model Statement: Kudos to Kering and LVMH. Fashion Law Institute. Available from: https://fashionlawinstitute.com/cutting-edge-articles/model-statement-kudos-kering-lvmh [accessed: November 19, 2020]

[18] Model Alliance. Available from: www.modelalliance.org [accessed: November 19, 2020].

[19] Rodgers RF, Ziff S, Lowy AS, et al. Results of a strategic science study to inform policies targeting extreme thinness standards in the fashion industry. Int J Eat Disord. 2017; 50: 284-292.

[20] Respect. In: Model Alliance. Available from: https://programforrespect.org [accessed: November 19, 2020].

[21] Condé Nast International announces Code of Conduct. Vogue Britain, 31 January 2018. Available from: https://www.vogue. co.uk/article/conde-nast-international-code-of-conduct [accessed: November 20,2020].

[22] The Model's Health Pledge. Available from: https://themodelshealthpledge.com [accessed: November 20, 2020].

(Túry Ferenc dr., Érd, Áfonya u. 46., 2030 e-mail: turyferenc@gmail.com)

\section{"Formosa facies muta commendatio est." (A szép arc néma ajánlás.)}

A cikk a Creative Commons Attribution 4.0 International License (https://creativecommons.org/licenses/by/4.0/) feltételei szerint publikált Open Access közlemény, melynek szellemében a cikk bármilyen médiumban szabadon felhasználható, megosztható és újraközölhetö, feltéve, hogy az eredeti szerzỏ és a közlés helye, illetve a CC License linkje és az esetlegesen végrehajtott módosítások feltüntetésre kerülnek. (SID_1) 